\title{
The Role of Frozen-Section in the Surgical Management of Patients with Endometrial Intraepithelial Neoplasia
}

\author{
Frozen Değerlendirmenin Endometrial İntraepitelyal Neoplazili \\ Hastaların Cerrahi Tedavisindeki Rolü
}

\author{
Mehmet Coşkun SALMAN' ${ }^{1}$, Derman BAŞARAN ${ }^{1}$, Alp USUBÜTÜN² ${ }^{2}$ Nejat ÖZGÜL' ${ }^{1}$ Kunter YÜCE ${ }^{1}$ \\ Department of 'Obstetrics and Gynaecology and ${ }^{2}$ Pathology, Hacettepe University Faculty of Medicine, ANKARA, TURKEY
}

\begin{abstract}
Objective: Patients with endometrial intraepithelial neoplasia may have concurrent endometrial cancer if managed surgically or develop cancer in time if managed conservatively. Therefore, intraoperative assessment of the uterus may be helpful if a surgical approach is decided on. Our study aimed to investigate the role of frozen-section examination in patients with endometrial intraepithelial neoplasia.
\end{abstract}

Material and Method: Patients with endometrial intraepithelial neoplasia who were subjected to hysterectomy with intraoperative frozen-section assessment were included. Main outcome measures were the rates of concurrent endometrial cancer and concurrent high-risk endometrial cancer as well as the efficacy of frozen-section in the detection of concurrent invasive disease and in the designation of low-risk and high-risk features.

Results: The study group consisted of seventy-three patients. Permanent pathology revealed endometrial adenocarcinoma in $19.2 \%$ whereas only one patient (1.4\%) had high-risk disease necessitating surgical staging. Frozen-section diagnoses were consistent with final pathology in $93.2 \%$ of patients in terms of the presence or absence of co-existent carcinoma. When frozen-section reports were further evaluated in terms of the presence or absence of high-risk endometrial carcinoma, consistency with the final pathology was seen in $98.6 \%$ of patients.

Conclusion: Co-existent endometrial cancer is not uncommon in endometrial intraepithelial neoplasia. Intraoperative frozen-section evaluation should therefore be considered whenever possible. Frozen-section is effective in the detection of coexistent invasive disease and in the designation of low-risk features. Although coexistent high-risk cancer is extremely rare, frozen-section assessment is not successful in determining high-risk features. Therefore, a re-staging surgery may be required on rare occasions.

Key Words: Endometrial hyperplasia, Intraepithelial neoplasm, Endometrial cancer, Frozen-section

(Turk Patoloji Derg 2015, 31:181-187)

Received : 15.07.2015 Accepted : 10.08.2015
ÖZ

Amaç: Endometrial intraepitelyal neoplazi tanısı olan hastalarda cerrahi sonrasında eşzamanlı endometrial kanser saptanabilir veya konservatif tedavi yaklaşımında zaman içinde kanser gelişebilir. Bu nedenle cerrahi yaklaşım kararı verilmiş ise uterusun intraoperatif değerlendirilmesi yararlı olabilir. Çalışmamızda endometrial intraepitelyal neoplazi olan hastalarda frozen kesit incelemesinin rolünün araştırılması amaçlanmıştır.

Gereç ve Yöntem: Çalışmaya histerektomi sırasında intraoperatif frozen kesit değerlendirmesi yapılan endometrial intraepitelyal neoplazi tanılı hastalar dahil edildi. Değerlendirilen sonuçlar içinde esas olarak eşzamanlı endometrium kanseri ve eşzamanlı yüksek riskli endometrial kanser oranları yanı sıra eşzamanlı invaziv hastalığın saptanmasında ve düşük-yüksek riskli özelliklerin belirlenmesinde frozen kesit incelemenin etkinliği yer aldı.

Bulgular: Çalışma grubu 73 hastadan oluştu. Kalıcı kesitlerin incelenmesi sonucunda \%19,2 oranında endometrial adenokarsinom saptanırken bu hastaların sadece bir tanesinde $(\% 1,4)$ cerrahi evreleme gerektiren yüksek riskli hastalık mevcuttu. Eşzamanlı karsinom varlığı veya yokluğu açısından karşılaştırma yapıldığında frozen ile nihai tanılar arasında \% 93,2 oranında uyum saptandı. Ayrıca yüksek riskli endometrial karsinom varlığı veya yokluğu açısından değerlendirildiğinde, frozen ile nihai tanılar arasında tutarlılık \%98,6 olarak görüldü.

Sonuç: Endometrial intraepitelyal neoplaziye eşlik eden endometrial kanserler nadir değildir. İntraoperatif frozen kesit değerlendirme bu nedenle mümkün olduğunca dikkate alınmalıdır. Frozen kesit eşlik eden invaziv hastalık tespiti ve düşük riskli özelliklerin belirlenmesinde etkilidir. Eşlik eden yüksek riskli kanser çok nadir olmakla birlikte, frozen kesit değerlendirmesi yüksek riskli özelliklerin belirlenmesinde başarılı değildir. $\mathrm{Bu}$ nedenle, yeniden evreleme cerrahisi nadiren gerekebilir.

Anahtar Sözcükler: Endometrial hiperplazi, İntraepitelyal neoplazm, Endometrial kanser, Frozen kesit

Correspondence: Mehmet Coşkun SALMAN

Hacettepe Üniversitesi Tıp Fakültesi, Kadın Hastalıkları ve Doğum Anabilim Dalı, 06100, Sihhiye, ANKARA, TURKEY

E-mail: csalman@hacettepe.edu.tr Phone: +90312 3051805 


\section{INTRODUCTION}

Endometrial carcinoma is the most common gynecologic cancer in developed countries (1). The most common subtype is endometrioid type endometrial adenocarcinoma which is detected in $80-85 \%$ of cases and usually develops from a precursor lesion (2-4). However, the diagnosis as well as management of these precursor lesions has long been a challenge. This is partly caused by the classification of these lesions. The most commonly used classification system for endometrial precancers is the World Health Organization (WHO) 1994 classification (5-7). Nevertheless, there is considerable interobserver and intraobserver diagnostic variation resulting largely from the subjective diagnostic criteria of this classification. Also, the WHO classification of the lesion does not guide the clinical management. A more objective endometrial intraepithelial neoplasia (EIN) classification was therefore introduced to identify patients at risk of having real precancer and to guide the clinician (8-11).

A significant proportion of patients with a biopsy diagnosis of EIN are found to have concurrent endometrial cancer if managed surgically or develop cancer in time if managed conservatively $(12,13)$. Intraoperative assessment of uterus for concurrent carcinoma is therefore recommended when surgical management is decided on. Although endometrial cancers associated with EIN diagnosed in the hysterectomy specimen are usually low-grade and early stage lesions with a negligible risk of extrauterine spread, there is always a possibility that a concurrent high-risk endometrial cancer may be detected (4). Accordingly, comprehensive surgical staging including systematic lymphadenectomy may be required. A decision to proceed with staging at the time of surgery depends on the presence and depth of myometrial invasion, the grade of disease, and the diameter of the tumor (14). Frozen-section examination was used in several studies to accurately reveal such tumor characteristics and therefore guide the extent of surgery in patients with endometrioid type endometrial carcinoma $(15,16)$. However, very little data exists in the literature regarding the performance of intraoperative frozen-section consultation in women with endometrial precancers (4).

This study aimed to assess the rate of concurrent endometrial cancer and concurrent high-risk endometrial cancer as well as the role of intraoperative frozen-section examination in patients with a preoperative diagnosis of EIN.

\section{MATERIAL and METHOD}

Consecutive patients who were subjected to hysterectomy with intraoperative frozen-section consultation within 4 weeks following a diagnosis of EIN at Hacettepe University Faculty of Medicine, Department of Obstetrics and Gynaecology between January 2009 and November 2013 were prospectively included in the study. The clinical and histopathological data of these patients were recorded in study-specific forms. Patients underwent endometrial sampling via Karman vacuum aspiration under local anesthesia in the office setting. Dilatation and curettage under general anesthesia in the operation theatre was used if sampling could not be performed without cervical dilatation or Karman endometrial aspiration did not produce a diagnostic specimen. The patients whose sampling procedure was performed outside our hospital were excluded from the study unless the pathology slides were obtained and re-examined by the co-author pathologist to confirm the EIN diagnosis. Patients with EIN who were treated surgically without a frozen-section examination were also excluded.

The co-author gynecological pathologist reviewed all endometrial sampling specimens according to the EIN classification system. Cases with EIN were diagnosed by using the subjective diagnostic criteria described by Hecht et al. on routine microscopic examination (3). Accordingly, the sample was diagnosed with EIN if the following criteria were met: (a) area of glands exceeds area of stroma, (b) epithelial cells within the architecturally crowded focus are cytologically different than the background, (c) the maximal linear dimension of the lesion exceeds $1 \mathrm{~mm}$, and (d) benign mimics and carcinoma were excluded.

All surgeries were performed under general anesthesia through amidline laparotomy incision. Following peritoneal washing cytology, an exploration of the abdomen and pelvis was performed to detect signs of extrauterine disease. Afterwards, total abdominal hysterectomy (TAH) was done and the specimen was sent to the pathologist for intraoperative assessment. Bilateral salpingooophorectomy (BSO) was performed in addition to hysterectomy if the patient was postmenopausal or aged 45 years and over or frozen-section consultation revealed endometrial adenocarcinoma.

Intraoperative examination of the specimen consisted of gross evaluation followed by division of the uterus in the coronal plane and inspection of the endometrial cavity for irregularities or masses (Figure 1). Areas suspicious for invasive disease were sampled for microscopic evaluation. Only one section was evaluated in cases with no macroscopic lesion. When microscopic evaluation revealed endometrial carcinoma, the grade of the disease (grade 1-2 or grade 3), maximal diameter of the lesion ( $\leq 2$ 


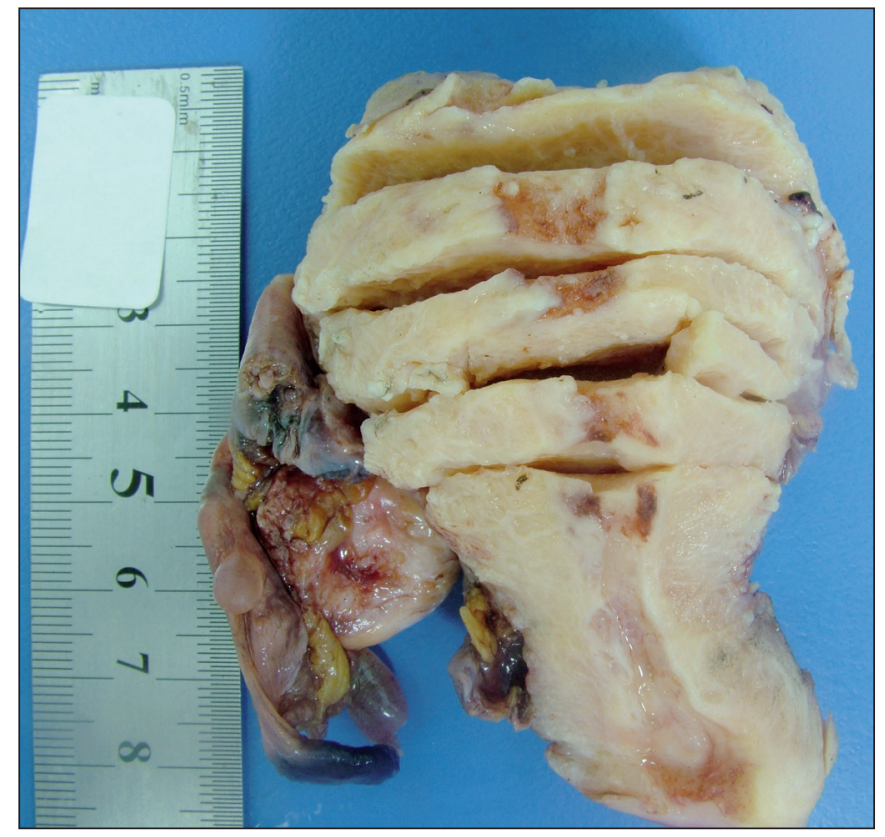

Figure 1: Macroscopy of uterus with minimal endometrial irregularities during intraoperative consultation diagnosed as well-differentiated endometrial adenocarcinoma.

$\mathrm{cm}$ or $>2 \mathrm{~cm}$ ) and the presence or absence of myometrial invasion were evaluated. In cases with myometrial invasion, the depth of myometrial invasion was reported as either superficial (invasion confined to the inner half of the myometrium) or deep (invasion detected in the outer half of the myometrium). Based on these characteristics, endometrial cancer was designated as low-risk or highrisk in terms of the risk for extrauterine spread and thereby the need for a comprehensive surgical staging was assessed according to Mayo criteria (14). Total abdominal hysterectomy with bilateral salpingo-oophorectomy was accepted to be adequate in patients with low-risk cancer whereas patients with high-risk cancer were considered to require comprehensive surgical staging including retroperitoneal lymph node dissection.

The specimens were finally examined by the gynecological pathologist for the permanent report. The revised FIGO staging system (17) was used to define the surgical stage of the patients with endometrial cancer.

The frozen-section diagnoses were compared with the final pathological diagnoses and the sensitivity, specificity, positive predictive value (PPV) and negative predictive value (NPV) of frozen-section in the detection of concurrent EC were calculated.

SPSS version 21 (SPSS Inc., Chicago, IL, USA) was used for the record of data and statistical analyses. Chi-square and
Fisher's exact tests were used, as appropriate, to compare nominal variables and the t-test was used to compare means. $P$ values less than 0.05 were considered significant.

\section{RESULTS}

A total of 86 consecutive patients were identified. Thirteen patients without intraoperative frozen examination were excluded and the study group consisted of 73 patients. EIN was diagnosed at our center in 65 patients (89.0\%). In the remaining 8 patients who were referred to our department after endometrial sampling, the diagnoses were confirmed by our pathologist before surgery.

The mean age of the study group was 51.0 years (range; 31 79 years). Of the patients, 30 (41.1\%) were postmenopausal and presented with postmenopausal bleeding whereas 43 premenopausal patients (58.9\%) had complaints of heavy and/or irregular menstrual bleeding during the initial presentation.

Permanent pathology revealed an endometrioid type endometrial adenocarcinoma in 14 patients (19.2\%). Patients finally diagnosed as having endometrial cancer were significantly older $(49.0 \pm 7.3$ vs. $59.6 \pm 11.6, \mathrm{p}<0.001)$. Also, the frequency of cancer was significantly higher in postmenopausal women compared to premenopausal patients $(9.3 \%$ vs. $33.3 \%, \mathrm{p}=0.01)$.

The characteristics of the 14 patients with concurrent endometrial cancer are shown in Table I. All but one (92.9\%) had grade 1 disease. Nine (64.3\%) had microscopic tumor whereas only $2(14.3 \%)$ had a tumor larger than 2 $\mathrm{cm}$. The disease was confined to the endometrium in 8 (51.7\%) and deep myometrial invasion was detected in only $1(7.1 \%)$.

According to histopathological characteristics, only 1 patient $(1.4 \%$ in all patients and $7.1 \%$ in patients with concurrent endometrial cancer) had high-risk disease necessitating comprehensive surgical staging while the remaining 13 patients had low-risk endometrial cancer without significant risk for extrauterine spread when Mayo criteria (14) were used. High-risk disease was due to both deep myometrial invasion and tumor diameter in this particular case (Table I).

In terms of the presence or absence of concurrent endometrial cancer, frozen-section diagnoses were consistent with the final pathology in 68 of 73 patients (93.2\%). In other words, the frozen examination missed endometrial cancer in 5 cases (6.8\%) within the study group. All these missed cases had grade 1, microscopic disease without any gross masses. The disease was confined to the 
Table I: Characteristics of patients with a final diagnosis of endometrial cancer

\begin{tabular}{|c|c|c|c|c|c|c|c|}
\hline Case & Age & Grade & Myometrial invasion & Tumor size & Frozen section diagnosis & Surgery & Final diagnosis \\
\hline 1 & 45 & 1 & none & microscopic & No EC & TAH+BSO & Low-risk EC \\
\hline 2 & 48 & 1 & none & microscopic & No EC & TAH+BSO & Low-risk EC \\
\hline 3 & 51 & 1 & none & microscopic & No EC & TAH+BSO & Low-risk EC \\
\hline 4 & 61 & 1 & superficial & microscopic & No EC & TAH+BSO & Low-risk EC \\
\hline 5 & 79 & 1 & none & microscopic & No EC & TAH+BSO & Low-risk EC \\
\hline 6 & 50 & 1 & superficial & $\leq 2 \mathrm{~cm}$ & Low-risk EC & TAH+BSO & Low-risk EC \\
\hline 7 & 54 & 1 & none & microscopic & Low-risk EC & TAH+BSO & Low-risk EC \\
\hline 8 & 61 & 1 & none & $\leq 2 \mathrm{~cm}$ & Low-risk EC & TAH+BSO & Low-risk EC \\
\hline 9 & 66 & 1 & none & microscopic & Low-risk EC & TAH+BSO & Low-risk EC \\
\hline 10 & 77 & 1 & superficial & microscopic & Low-risk EC & TAH+BSO & Low-risk EC \\
\hline 11 & 72 & 1 & none & $>2 \mathrm{~cm}$ & Low-risk EC & TAH+BSO & Low-risk EC \\
\hline 12 & 56 & 2 & superficial & microscopic & Low-risk EC & TAH+BSO & Low-risk EC \\
\hline 13 & 45 & 1 & superficial & $\leq 2 \mathrm{~cm}$ & Low-risk EC & TAH+BSO & Low-risk EC \\
\hline 14 & 69 & 1 & deep & $>2 \mathrm{~cm}$ & Low-risk EC & TAH+BSO & High-risk EC \\
\hline
\end{tabular}

EC: Endometrial cancer, TAH: Total abdominal hysterectomy, BSO: Bilateral salpingo-oophorectomy.

Table II: Frozen section diagnoses vs. final pathology results in terms of the presence or absence of endometrial cancer

\begin{tabular}{|l|c|c|c|}
\hline \multirow{2}{*}{$\begin{array}{l}\text { Frozen section } \\
\text { diagnosis (n) }\end{array}$} & \multicolumn{2}{|c|}{ Final pathology result (n) } & \multirow{2}{*}{ Total } \\
\cline { 2 - 4 } No EC & No EC & EC & \\
\hline EC & 59 & 5 & 64 \\
\hline Total & - & 9 & 9 \\
\hline
\end{tabular}

EC: Endometrial cancer.

endometrium in four and superficial myometrial invasion was detected in the remaining patient. Therefore, none of those frozen-missed cases had high-risk endometrial cancer and they accordingly did not require staging surgery. All underwent total abdominal hysterectomy with bilateral salpingo-oophorectomy. Hence, a secondary staging surgery was not required for any of the frozen-missed cases. The sensitivity, specificity, positive predictive value, and negative predictive value of frozen examination for the diagnosis of concurrent endometrial carcinoma in women operated for endometrial intraepithelial neoplasia were $64.3 \%, 100.0 \%, 100.0 \%$, and $92.2 \%$, respectively (Table II).

When frozen-section reports were further evaluated in terms of the presence or absence of high-risk endometrial carcinoma, consistency with the final pathology was seen in 72 patients (98.6\%). Intraoperative frozen evaluation could not detect the unique case with high-risk endometrial carcinoma who required staging surgery. That patient was a 69-year-old woman who presented with postmenopausal bleeding. She was subjected to total abdominal hysterectomy with bilateral salpingo-oophorectomy. Her frozen-section revealed well-differentiated endometrial adenocarcinoma forming a polypoid mass within the cavity with no apparent myometrial invasion. Therefore, no further surgery was done. However, final pathology showed grade 1 endometrial carcinoma of the endometrioid type with a maximal diameter of $4.5 \mathrm{~cm}$ that had deep myometrial infiltration. The patient was recommended re-staging surgery due to the risk of extrauterine spread but she declined to have a second operation and external pelvic radiation was administered. She is alive without disease 24 months after the initial diagnosis.

\section{DISCUSSION}

Endometrial adenocarcinoma develops from a precursor lesion in most cases (2-4). This precursor lesion is designated as either complex atypical endometrial hyperplasia or endometrial intraepithelial neoplasia (EIN) (5-11).

A diagnosis of atypical endometrial hyperplasia confers more than 10-fold increased risk and a diagnosis of EIN heralds a 45-fold increased risk of developing endometrial cancer $(18,19)$. These facts justify those pathologies to be considered as precursor lesions. On the other hand, although the word "precursor" lexically means "an indicator of an approaching event or an event that precedes another event", some of the patients with endometrial cancer precursor will be found to have undiagnosed co-existent invasive disease if 
they are subjected to immediate surgical treatment $(12,13)$. Moreover, the rate of co-existent endometrial carcinoma is not so low and in the literature this rate was reported to vary from $15 \%$ to $40 \%$ in different series when patients are managed with immediate surgery $(12,13,20-24)$. Similar to these figures, the rate of co-existent carcinoma was 19.2\% in the current series. Most of the patients with co-existent endometrial carcinoma have low-grade disease with no or superficial myometrial invasion (12,21-24). Therefore, simple hysterectomy plus salpingo-oophorectomy without a comprehensive staging procedure will warrant a sufficient surgical approach since the malignant disease is accepted to be a low-risk one (14). However, in some patients, highrisk features such as large tumor, grade 3 disease and/or deep myometrial invasion may be detected $(12,21,-23)$. Extrauterine disease may be seen as well (12). As a result, EIN is associated with co-existent high-risk endometrial cancer in $7-13 \%$ of the patients $(12,23)$. Although none of the patients had high-grade disease in our series, deep myometrial invasion was found in $7.1 \%$ of the patients with endometrial carcinoma and a large tumor was found in $14.3 \%$. Based on these findings, $7.1 \%$ of patients with coexistent carcinoma and $1.4 \%$ of all patients with EIN had high-risk endometrial cancer in the current series.

There is certainly a group of patients with a biopsy diagnosis of EIN who has co-existent endometrial cancer and although the rate is much lower some of those with co-existent cancer would require comprehensive surgical staging due to high-risk features. The challenge is how to identify these patients. Intraoperative evaluation of the hysterectomy specimen by frozen-section in women with endometrioid type endometrial cancer has been shown to successfully reveal tumor characteristics including grade, size and depth of myometrial invasion. The extent of surgery may be decided accordingly $(15,16)$. The same principle may be adapted into the surgical management of patients with EIN. On the other hand, very little data is available in the literature regarding the role of intraoperative frozen-section examination in the decision-making of the gynecologist (4). Moreover, the available limited data mostly includes patients with atypical endometrial hyperplasia and it shows only $40-50 \%$ sensitivity of frozen-section assessment even in the identification of the presence or absence of endometrial carcinoma in patients with endometrial precancers $(25,26)$.

In our study, intraoperative frozen-section analysis of the hysterectomy specimens among patients with EIN was found to be a useful diagnostic tool for the detection of co-existent endometrial carcinoma. Frozen assessment detected $64.3 \%$ of these co-existent cancers. Also, frozen assessment accurately identified low-risk features in 61.5\% of all co-existent cancers which prevented unnecessary staging surgery. The positive predictive value of frozensection for the detection of co-existent cancer was $100 \%$. This means that the gynecologic surgeon who is operating on a patient with EIN may perform bilateral salpingo-oophorectomy with no hesitation if concurrent endometrial carcinoma is reported by frozen assessment given that synchronous endometrial and ovarian cancer is not so uncommon especially among young women (27). However, the negative predictive value of intraoperative assessment for the detection of co-existent cancer was lower. Therefore, a negative intraoperative report does not exclude the presence of cancer. Fortunately, hysterectomy with salpingo-oophorectomy was sufficient in all frozenmissed cancer cases because the malignant disease was microscopic only, with low risk features.

On the other hand, intraoperative frozen-section examination failed to detect high-risk features of the unique case who necessitated staging surgery due to large tumor and deep myometrial invasion in this study group. In that case, the frozen-section analysis missed high-risk endometrial cancer due to misinterpretation of the depth of myometrial invasion. Intraoperative assessment of myometrial invasion in endometrial cancer has already been reported as a debatable subject and such an assessment is congruent with the final diagnosis in approximately $70 \%$ of patients $(28,29)$. Combination of preoperative magnetic resonance imaging and intraoperative frozen-section may help overcome this issue with added costs (30). Some may also consider doing a staging surgery in all patients with EIN which is not acceptable because it would be an overtreatment in $98.6 \%$ of patients in this series. Another option is to perform simple hysterectomy and to suggest a restaging procedure if necessary after obtaining a permanent pathology report. Such an approach has the well-known increased risks related to a secondary surgery, but it seems to be the most reasonable strategy due to the considerably low incidence of high-risk concurrent endometrial cancer.

In conclusion, this is the first study to best of our knowledge that investigated the accuracy of frozen section analysis exclusively in patients with a biopsy diagnosis of EIN who were scheduled for immediate surgical treatment. According to our results, the incidence of co-existent endometrial cancer is about $20 \%$ in EIN and the incidence is higher if the patient is older or post-menopausal. Intraoperative evaluation should therefore be considered during the surgical management. Frozen-section is effective in the detection of co-existent invasive disease and 
in the designation of low-risk features. Co-existent highrisk disease necessitating staging surgery is extremely rare and frozen-section analysis is not successful in detecting high-risk features. However, this judgment arises from a unique case in this series and larger series with more patients having co-existent high-risk disease are required to decide whether frozen-section is effective or not in the identification of high-risk features.

\section{REFERENCES}

1. Jemal A, Bray F, Center MM, Ferlay J, Ward E, Forman D. Global cancer statistics. CA Cancer J Clin. 2011;61:69-90.

2. Cavanagh D, Fiorica JV, Hoffman MS, Durfee J, Nicosia SV. Adenocarcinoma of the endometrium: An institutional review. Cancer Control. 1999;6:354-60.

3. Hecht JL, Ince TA, Baak JP, Baker HE, Ogden MW, Mutter GL. Prediction of endometrial carcinoma by subjective endometrial intraepithelial neoplasia diagnosis. Mod Pathol. 2005;18:324-30.

4. Trimble CL, Method M, Leitao M, Lu K, Ioffe O, Hampton M, Higgins R, Zaino R, Mutter GL; Society of Gynecologic Oncology Clinical Practice Committee. Management of endometrial precancers. Obstet Gynecol. 2012;120:1160-75.

5. Kurman RJ, Kaminski PF, Norris HJ. The behavior of endometrial hyperplasia: A long-term study of "untreated" hyperplasia in 170 patients. Cancer. 1985;56:403-12.

6. Tavassoli FA, Stratton MR, editors. WHO classification of tumors: Pathology and genetics of tumors of the breast and female genital organs. Lyon: IARC Press; 2003.

7. Widra EA, Dunton CJ, McHugh M, Palazzo JP. Endometrial hyperplasia and the risk of carcinoma. Int J Gynecol Cancer. 1995;5:233-5.

8. Skov BG, Broholm H, Engel U, Franzmann MB, Nielsen AL, Lauritzen AF, Skov T. Comparison of the reproducibility of the WHO classifications of 1975 and 1994 of endometrial hyperplasia. Int J Gynecol Pathol. 1997;16:33-7.

9. Bergeron C, Nogales FF, Masseroli M, Abeler V, Duvillard P, Müller-Holzner E, Pickartz H, Wells M. A multicentric European study testing the reproducibility of the WHO classification of endometrial hyperplasia with a proposal of a simplified working classification for biopsy and curettage specimens. Am J Surg Pathol. 1999;23:1102-8.

10. Usubutun A, Ertoy D, Ozkaya O, Altinok G, Kucukali T. Search for problem areas in endometrial biopsies to achieve quality assurance. Pathol Res Pract. 2000;196:625-6.

11. Mutter GL. Endometrial intraepithelial neoplasia (EIN): Will it bring order to chaos? The Endometrial Collaborative Group. Gynecol Oncol. 2000;76:287-90.

12. Semere LG, Ko E, Johnson NR, Vitonis AF, Phang LJ, Cramer DW, Mutter GL. Endometrial intraepithelial neoplasia: Clinical correlates and outcomes. Obstet Gynecol. 2011;118:21-8.

13. Salman MC, Usubutun A, Boynukalin K, Yuce K. Comparison of $\mathrm{WHO}$ and endometrial intraepithelial neoplasia classifications in predicting the presence of coexistent malignancy in endometrial hyperplasia. J Gynecol Oncol. 2010;21:97-101.
14. Mariani A, Dowdy SC, Cliby WA, Gostout BS, Jones MB, Wilson TO, Podratz KC. Prospective assessment of lymphatic dissemination in endometrial cancer: A paradigm shift in surgical staging. Gynecol Oncol. 2008;109:11-8.

15. Kucera E, Kainz C, Reinthaller A, Sliutz G, Leodolter S, Kucera $\mathrm{H}$, Breitenecker G. Accuracy of intraoperative frozen-section diagnosis in stage I endometrial adenocarcinoma. Gynecol Obstet Invest. 2000;49:62-6.

16. Noumoff JS, Menzin A, Mikuta J, Lusk EJ, Morgan M, LiVolsi VA. The ability to evaluate prognostic variables on frozen section in hysterectomies performed for endometrial carcinoma. Gynecol Oncol. 1991;42:202-8.

17. Pecorelli S. Revised FIGO staging for carcinoma of the vulva, cervix, and endometrium. Int J Gynaecol Obstet. 2009;105:103-4.

18. Lacey JV Jr, Ioffe OB, Ronnett BM, Rush BB, Richesson DA, Chatterjee N, Langholz B, Glass AG, Sherman ME. Endometrial carcinoma risk among women diagnosed with endometrial hyperplasia: The 34-year experience in a large health plan. Br J Cancer. 2008;98:45-53.

19. Baak JP, Mutter GL, Robboy S, van Diest PJ, Uyterlinde AM, Orbo A, Palazzo J, Fiane B, Løvslett K, Burger C, Voorhorst F, Verheijen RH. The molecular genetics and morphometrybased endometrial intraepithelial neoplasia classification system predicts disease progression in endometrial hyperplasia more accurately than the 1994 World Health Organization classification system. Cancer. 2005;103:2304-12.

20. Kane SE, Hecht JL. Endometrial intraepithelial neoplasia terminology in practice: 4 -year experience at a single institution. Int J Gynecol Pathol. 2012;31:160-5.

21. Ørbo A, Kaino T, Arnes M, Larsen K, Pettersen I, Moe B. Prognostic markers for coexistent carcinoma in high-risk endometrial hyperplasia with negative D-score: Significance of morphometry, hormone receptors and apoptosis for outcome prediction. Acta Obstet Gynecol Scand. 2009;88:1234-42.

22. Ørbo A, Moe BT, Arnes M, Pettersen I, Larsen K, Eggen T, Myrmel K, Hanssen K. Prognostic markers for detection of coexistent carcinoma in high-risk endometrial hyperplasia. Anticancer Res. 2010;30:4649-55.

23. Mutter GL, Kauderer J, BaakJP, Alberts D; Gynecologic Oncology Group. Biopsy histomorphometry predicts uterine myoinvasion by endometrial carcinoma: A Gynecologic Oncology Group study. Hum Pathol. 2008;39:866-74.

24. Pavlakis K, Messini I, Vrekoussis T, Panoskaltsis T, Chrissanthakis D, Yiannou P, Stathopoulos EN. PTEN-loss and nuclear atypia of EIN in endometrial biopsies can predict the existence of a concurrent endometrial carcinoma. Gynecol Oncol. 2010;119:516-9.

25. Indermaur MD, Shoup B, Tebes S, Lancaster JM. The accuracy of frozen pathology at time of hysterectomy in patients with complex atypical hyperplasia on preoperative biopsy. Am J Obstet Gynecol. 2007;196:e40-2.

26. Bilgin T, Ozuysal S, Ozan H, Atakan T. Coexisting endometrial cancer in patients with a preoperative diagnosis of atypical endometrial hyperplasia. J Obstet Gynaecol Res. 2004;30:205-9. 
27. Signorelli M, Fruscio R, Lissoni AA, Pirovano C, Perego P, Mangioni C. Synchronous early-stage endometrial and ovarian cancer. Int J Gynaecol Obstet. 2008;102:34-8.

28. Kumar S, Bandyopadhyay S, Semaan A, Shah JP, Mahdi H, Morris R, Munkarah A, Ali-Fehmi R. The role of frozen section in surgical staging of low risk endometrial cancer. PLoS One. 2011;6:e21912.

29. Case AS, Rocconi RP, Straughn JM Jr, Conner M, Novak L, Wang W, Huh WK. A prospective blinded evaluation of the accuracy of frozen section for the surgical management of endometrial cancer. Obstet Gynecol. 2006;108:1375-9.

30. Hahn HS, Song HS, Lee IH, Kim TJ, Lee KH, Shim JU, Kim JW, Lim KT. Magnetic resonance imaging and intraoperative frozen sectioning for the evaluation of risk factors associated with lymph node metastasis in endometrial cancer. Int J Gynecol Cancer. 2013;23:1411-6. 